Article

\title{
An Evolving Agricultural Extension Model for Lasting Impact: How Willing Are Tanzanian Farmers to Pay for Extension Services?
}

\author{
Rodrigo Abed ${ }^{1, *(D)}$, Haroon Sseguya ${ }^{2}$, James Flock ${ }^{1}$, Silvanus Mruma ${ }^{3}$ and Hamisi Mwango ${ }^{3}$ \\ 1 ACDI/VOCA, 50 F Street NW, Suite 1000, Washington, DC 20001, USA; jflock@nafaka-tz.org \\ 2 International Institute of Tropical Agriculture (IITA), Regional Hub for Eastern Africa, \\ P.O. Box 34441 Dar es Salaam, Tanzania; h.sseguya@cgiar.org \\ 3 ACDI/VOCA, Feed the Future Tanzania NAFAKA II Activity, P.O. Box 185 Iringa, Tanzania; \\ smruma@nafaka-tz.org (S.M.); hmwango@nafaka-tz.org (H.M.) \\ * Correspondence: rodrigoabedm@gmail.com
}

Received: 27 September 2020; Accepted: 11 October 2020; Published: 14 October 2020

\begin{abstract}
Community-based extension services (CES) are vital for improving farmers' livelihoods, but most of them face a challenge of sustainability after phasing out of the externally funded initiatives that they are part of. This study estimated farmer's willingness to pay (WTP) for four types of agricultural extension services (AES) in the cereals' value chains provided as a part of two United States Agency for International Development (USAID)-funded Feed the Future initiatives in Tanzania. Data were collected from 595 smallholder cereal farmers using a primary survey in four districts of the Southern Highlands. We implemented a double-bounded dichotomous choice contingent valuation method. Average WTP figures ranged from 20,000 to 24,000 TZS (8-10 USD) depending on the type of AES. Several socioeconomic and agriculture-related variables influenced smallholders' WTP for the extension services. This research explored the feasibility of a farmer-led model as a pathway to delink extension services from public and donor funding to achieve sustainable rural development. Farmers place a monetary value on extension services indicating that policymakers and practitioners should make further efforts to enhance a community's ability to achieve self-reliance through investments in CES.
\end{abstract}

Keywords: extension services; willingness to pay; contingent valuation method; sustainability; pluralistic extension services providers; Tanzania

\section{Introduction}

Poverty and food insecurity persist in Sub-Saharan African (SSA) countries at a rate of $41 \%$ and $23 \%[1,2]$, respectively, and the majority of the population is dependent on agriculture for their livelihoods [3]. Since poverty and food insecurity are mainly rural phenomena, the UN recognizes the importance of increasing agricultural productivity as a means to achieve two Sustainable Development Goals that aim at reducing poverty and hunger [4]. In Africa, the Comprehensive Africa Agriculture Development Programme (CAADP) has pledged to promote agriculture-led growth and has set an annual increase of $6 \%$ in agricultural growth as a target. The initiative's main pillars are related to (1) sustainable resource management, (2) facilitating market access and rural infrastructure, (3) hunger reduction, (4) agricultural research, and (5) technology dissemination. As of 2016, 46 CAADP member countries, including Tanzania, had signed the CAADP compact [5]. However, despite the efforts in place, agricultural productivity levels in most of Sub-Saharan African countries are still low [6] due to factors associated with inadequate access to improved agricultural technologies, information, credit, and market incentives. 
In Tanzania, agriculture is the mainstay of the national economy contributing over $27 \%$ of GDP and employing $78 \%$ of the labor force [7]. The majority of farmers are smallholders, managing about 1 hectare [8] and producing below potential for most enterprises [9]. According to the United Republic of Tanzania (URT) [10], the low agricultural productivity levels are a function of a multitude of factors, including low adoption of improved technologies, inadequate agricultural technical support services, poor infrastructure, pests and disease management, poor land management, and lack of secure tenures as well as inadequate gender relations, weak producer organizations, and poor market access. On the issue of technical support services, URT [10] further notes that the quality of extension services is hindered by poor research-extension-farmer linkages; low extension staffing and supervision; lack of delivery performance standards and regulations; and low participation of private sector as providers of extension services. Thus, from a policy perspective, the suggestion is that "extension services shall be transformed to ensure the provision of quality services with increased private sector participation" [10].

Agricultural extension services (AES) in Tanzania, like in many other SSA countries, have evolved over the years. Prior to 1999, when the Government of Tanzania (GoT) embraced decentralization, extension services were delivered using a top-down approach whereby staff of the Ministry of Agriculture were responsible for providing AES with personnel stationed at the ministry, region, and district levels. The district offices were part of the central government bureaucracy and worked under the instruction and supervision of regional offices [11]. This arrangement was criticized for being non-responsive to farmers' needs, with extension staff prioritizing orders from the ministry officials [12].

After 1999, agricultural extension services were decentralized to local governments (district, ward, and village levels), where local councils began to supervise extension staff. As part of the prevailing policies and programs, the government also increased its efforts to recruit more staff, to ensure that every village had at least one extension agent [13]. However, the decentralized extension services' system did not work as initially planned. For instance, under this arrangement, farmers were supposed to work closely with extension staff to articulate their needs, but in practice, this collaboration did not take place systematically. Moreover, even if farmers or farmers' organizations managed to articulate their needs with extension agents, the local programs did not, in most cases, reflect farmers' preferences [14].

Drawing from global developments in the delivery of extension services, the country has adopted a pluralistic approach in its extension plans and programs. The national agricultural policy advocates for improving the quality of AES through private sector participation [10]. The second Agricultural Sector Development Program (ASDP II), launched in 2018, also aims to ensure a wider network of service providers by integrating agribusiness services delivered by the private sector to support technical services provided by local governments [15]. This move by the GoT is in line with the Agricultural Innovation Systems (AIS) perspective suggested in modern development discourse whereby a broad range of actors and sectors, as well as the need to create an enabling environment for the generation and use of information, are recognized as a means to improve rural livelihoods [16,17].

As in much of Sub-Saharan Africa, maize and rice are staple crops in Tanzania and are primarily produced by smallholder farmers [18,19]. Even though farmers sell a portion of their harvest, they retain a large share for household consumption. These cereals represent a third of Tanzanian's calorie intake [20]. Maize production is around 6,000,000 MT, while rice production is over 3,000,000 MT, and combined, they occupy about $40 \%$ of the country's share of arable land [9]. The Southern Highlands, an agroecological zone characterized by maize surplus production and wetlands for paddy production, concentrates close to $60 \%$ of the cereals production and is considered the grain basket of the country [21].

According to FAOSTAT [9], maize and rice yields have remained stagnant and, given the estimated growth in demand for these crops and their importance to guarantee food security in the country, efforts need to be stepped up to increase productivity. The ASDP II highlights the role of extension services as a key factor to increase crop yields by using available resources and technologies more efficiently [15]. However, although commendable efforts have been put in place to recruit a larger number of extension staff, studies have shown that most villages in Tanzania have limited access to 
extension services [22]. A study by Hella [23] suggests that government extension agents reach only $10 \%$ of the farming households in Tanzania.

Extension services provided by the GoT are publicly funded and, thus, free for farmers. However, the reliance on government funding limits investments in human and logistical resources to extend the breadth of these services [15]. Consequently, donor programs are often implemented to overcome these conundrums. The United States Agency for International Development (USAID)-funded Feed the Future $(\mathrm{FtF})$ initiative is one of such of programs. FtF aims to harmonize regional hunger- and poverty-reduction efforts in countries with chronic food insecurity and insufficient production of staple crops and has been implemented in Tanzania since 2011 [24]. Two FtF-funded programs, NAFAKA II (meaning cereals in Kiswahili) and Africa RISING (Africa Research in Sustainable Intensification for the Next Generation) collaborate to increase agricultural productivity and, ultimately, improve the livelihoods of beneficiary communities. The NAFAKA II project, led by ACDI/VOCA, focuses on the development and strengthening of cereal market systems, thereby improving the productivity and competitiveness of the maize and rice value chains [25]. The Africa RISING project, led by the International Institute of Tropical Agriculture (IITA), focuses on creating opportunities for smallholder farm households to move out of hunger and poverty through sustainably intensified farming systems that improve food, nutrition, and income security, particularly for women and children, and conserve the natural resource base [26]. Given the centrality of agricultural extension services to address rural poverty and food insecurity [27], the two interventions made investments to fill gaps associated with public extension services in terms of low staffing [28]. The approach consisted in developing a system of community-based extension services (CES) by training village-based agricultural advisors (VBAAs), selected by farmers and village leaders, as well as leaders of Producer Organizations (POs) who then proceeded to share knowledge and provide other agricultural services in their communities. However, as indicated by Kiptot and Franzel [29], the challenge faced by CES established by donor-funded projects relates to their sustainability after these have ended. Some authors, such as Simpson et al. [30] and Kiptot and Franzel [29], suggest fiscal sustainability through institutionalization and mobilization of local resources. However, there is a dearth of empirical studies on the extent to which this can be realized in practice and which factors need to be prioritized with respect to the mobilization of resources. On the other hand, Shekara [31] indicates that farmer's participation in extension finance has been successfully implemented in several countries as a means to reduce their dependency on state government services. This approach is further supported by Kiptot and Franzel [32] who established that income generation is a major driver to guarantee sustainability of CES beyond the life of development projects.

In this context, the FtF projects hypothesized that, as they phase out, there will be a market for VBAAs and POs to provide extension services in exchange for a fee whereby, these qualified providers are readily available at the village level to assist farmers to fill knowledge gaps. The purpose of this study was to establish the extent to which farmers are willing to pay for extension services that are critical for increased productivity in the cereals' value chains, focusing on (1) integrated pest management, (2) postharvest handling, (3) business skills, and (4) land preparation, soil fertility, and water management. This is a particularly relevant effort to explore the feasibility of a fee-for service model led by farmers or farmer's associations that could guarantee the plurality of service providers and ensure sustained knowledge transfer at the village level by delinking extension services from public and donor funding.

\section{Methodology}

\subsection{Study Location and Sample}

The Government of Tanzania has a country development cooperation strategy (CDCS) with USAID that informs priority locations on where the donor programs will be implemented [33]. NAFAKA II and Africa RISING are both obligated through agreements with USAID, based on the CDCS, to work 
in preselected regions of the country. Because of the nature of the projects (cereals' value chains), they operate in the Southern Highlands.

This study was conducted in four different districts of the Southern Highlands of Tanzania that were purposely selected: Kilombero, Mbarali, Mbozi, and Kilolo. The first two are predominantly rice growing areas, and the latter are characterized by maize production. The selected districts also differ in productivity levels. Among maize-production districts, farmers in Mbozi consistently report higher yields than those in Kilolo, while for rice, Mbarali is a higher yielding district than Kilombero. A two-stage cluster sampling procedure was implemented. In the first stage, 10 villages were selected from each district using a random table, after assigning numbers to each village. In the second stage, 10 to 15 farmers were randomly selected per village. The sample size, which was determined using a power calculation, consisted of 595 farmers that were effectively interviewed with $100 \%$ response rate.

\subsection{Data Description}

A set of socioeconomic and demographic variables were included in the model to test their influence on farmers' willingness to pay. Age, household size, farming experience, land ownership, agricultural revenues, and off-farm income are all numerical variables, while the district the respondent belongs to, frequency of extension officer's visit, education and literacy levels, polygamist marriage, access to technology, and participation in a Producer Organization (PO) that receives training from NAFAKA II were measured at the nominal level (Table 1). These covariates were selected upon a thorough literature review where willingness to pay (WTP) was found to be a function of variables that influence social norms, asset ownership, revenues generated, budget constraints, crop productivity, demand, access and understanding of information, access to training, among others.

Table 1. Descriptive statistics and variables' definition.

\begin{tabular}{|c|c|c|c|}
\hline Variable & Definition & Mean & SD \\
\hline Male & $=1$ if respondent is a male, 0 otherwise & 0.65 & 0.48 \\
\hline Age & Age in groups * & 2.93 & 1.12 \\
\hline Literacy level & $=1$ if respondent is literate, 0 otherwise & 0.95 & 0.22 \\
\hline Education level & Highest level of education ** & 3.32 & 1.19 \\
\hline Polygamist marriage & $=1$ if respondent is polygamist, 0 otherwise & 0.11 & 0.32 \\
\hline Household size & Number of household members & 5.44 & 2.40 \\
\hline Farming experience & Years of farming experience & 17.82 & 11.65 \\
\hline Land ownership & Number of hectares of land owned & 1.60 & 1.90 \\
\hline Frequency of visit & $\begin{array}{l}\text { Frequency of extension agent's visit } * * * \\
=1 \text { if respondent belongs to a Producer }\end{array}$ & 2.19 & 1.14 \\
\hline NAFAKA II PO & $\begin{array}{c}\text { Organization that works with NAFAKA, } 0 \\
\text { otherwise }\end{array}$ & 0.39 & 0.49 \\
\hline Access to technology & $\begin{array}{c}=1 \text { if respondent has access to technology, } 0 \\
\text { otherwise }\end{array}$ & 0.92 & 0.28 \\
\hline Agricultural revenues & $\begin{array}{c}\text { Revenues from maize and rice sales in thousands of } \\
\text { Tanzanian shillings }\end{array}$ & 1233.48 & 1571.67 \\
\hline Off-farm income & $\begin{array}{l}\text { Off-farm income in thousands of Tanzanian } \\
\text { shillings }\end{array}$ & 463.37 & 1055.27 \\
\hline Kilolo & $=1$ if respondent is from Kilolo district, 0 otherwise & 0.24 & 0.43 \\
\hline Kilombero & $\begin{array}{c}=1 \text { if respondent is from Kilombero district, } 0 \\
\text { otherwise }\end{array}$ & 0.25 & 0.43 \\
\hline Mbozi & $=1$ if respondent is from Mbozi district, 0 otherwise & 0.24 & 0.43 \\
\hline Mbarali & $\begin{array}{c}=1 \text { if respondent is from Mbarali district, } 0 \\
\text { otherwise }\end{array}$ & 0.28 & 0.45 \\
\hline
\end{tabular}

* 5 categories were defined: $1=\leq 29,2=30-39,3=40-49,4=50-59,5=\geq 60$. ** 8 categories were defined: $1=$ no school, 2 = primary school not completed, $3=$ primary school completed, $4=$ secondary school not completed, $5=$ secondary school completed, $6=$ technical or vocational school, $7=$ tertiary not completed, $8=$ tertiary Completed. *** 4 categories were defined: $1=$ less than once a month, $2=$ once a month, $3=$ once every 2 weeks, $4=$ once a week. 
There is an almost even distribution of farmers in the districts surveyed with about a quarter of them in each location. However, Mbarali had slightly more respondents than the rest. More than half $(65 \%)$ of the sample was comprised by male farmers, and the largest portion of respondents was concentrated in the age range between 40 to 49 years old, reflecting a mature population. An older generation of farmers might be more reluctant to adopt new technologies and, thus, would be less willing to pay for extension services. The large majority (75\%) of farmers have completed primary school and literacy levels were reportedly high, with $95 \%$ of the sample being able to read and write. This indicates that farmers would be able to acquire knowledge through printed materials (handbooks, newsletters, flyers) that can be distributed by the government, academia, or the private sector. The mean household size was five members, and about $11 \%$ of respondents were in polygamist marriages. These last two variables impact the income and expenses of the household, thus influencing willingness to pay for AES.

On average, respondents had about 18 years of farming experience and owned 1.6 hectares of land. Close to $40 \%$ reported receiving visits from extension agents less often than once a month, which could be linked to low availability of government extension agents. Despite this situation, agricultural technology access seems to be quite high with $92 \%$ reporting to have access (agricultural technology in this study is defined as improved inputs, irrigation, mechanization, and postharvest technologies). About $40 \%$ of the farmers in the sample belonged to a Producer Organization that works with NAFAKA II. The project supports 345 POs by providing trainings on a variety of topics ranging from production practices to financial management and uses its grants program to subsidize the purchase of mechanization equipment, while also creating linkages with financial services institutions along with input and output cereal value chain actors.

Data on agricultural revenues and off-farm income were collected as a measure of operating capital. Agricultural income was not considered in the study, since at the time of conducting the survey, farmers had not yet sold all their grain stocks. Therefore, agricultural revenues generated as a result of partial sales were measured to avoid underestimating income values.

\subsection{Contingent Valuation Method}

The study implemented a double-bounded dichotomous choice contingent valuation method (CVM) to estimate farmer's willingness to pay for four types of agricultural extension services. This methodology is used to elicit the value of non-marketed goods and policies or projects that have not yet been implemented. Its name derives from the fact the values obtained are contingent on the scenarios presented to the respondent [34]. A detailed description and historical background of CVM can be found in [35-37].

In 1993, the National Oceanic and Atmospheric Administration (NOAA) panel released a report confirming that the methodology can produce valuable and reliable information but cautioned that to do so; researchers should comply with a set of guidelines to ensure that it yields accurate results [37]. Among the key recommendations were (1) the use of a probabilistic sample, (2) using close-ended questions instead of an open-ended format, (3) use of a referendum approach whereby respondents are given a chance to not cast their vote/opinion, (4) face-to-face interviews instead of phone interviews, (5) including covariates that would enable researchers to interpret willingness to pay results, and (6) reminding people of their income and expenses before responding to the valuation question.

This study adhered to each of these recommendations with special attention given to the second one. CVM was implemented by using dichotomous choice or close-ended questions, where respondents are offered predetermined values and are asked to accept or reject them [37].

\subsection{Dichotomous Choice Experiments-The Double-Bounded Model}

Bishop and Heberlein [38] proposed a single-bounded dichotomous choice model whereby respondents only faced one value or bid. If the bid offered was above the acceptable threshold, the respondent would reject it, while if it was below, the person would accept it. Hanemann, Loomis, 
and Kanninen [39] argued that the double-bounded model, that involves adding a follow-up question in which the second bid offered is lower or higher contingent on the response to the first question, increases the statistical efficiency of the estimate asymptotically. As illustrated in Figure 1, using 5000 TZS as an example, respondents were randomly offered one of four different initial bids (5000 TZS; 10,000 TZS; 15,000 TZS; and 20,000 TZS) for each of the scenarios, and depending on the responses to the first quantity, the following one would be higher or lower. The bids and their range were pre-tested and adjusted in consultation with the target population during the enumerators' training to ensure their validity and that of the rest of the survey instruments.

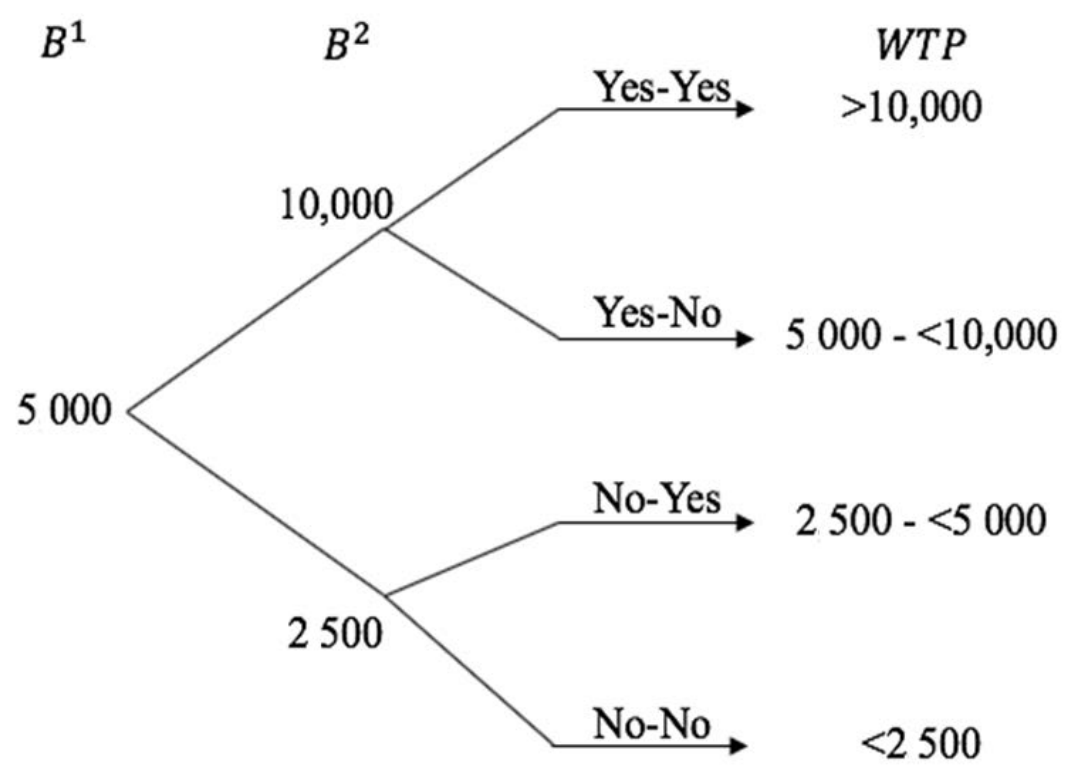

Figure 1. Structure of the scenarios of the double-bounded contingent valuation model. Note: $B^{1}$ : first bid, $B^{2}$ : second bid, WTP: willingness to pay.

Under this premise, and assuming the willingness to pay for agricultural extension services of an individual, $i$ can be modeled using the linear function,

$$
\operatorname{WTP}_{i}\left(x_{i}, \varepsilon_{i}\right)=x_{i} \alpha+\varepsilon_{i}
$$

where $x_{i}$ is a vector of explanatory variables, $\alpha$ is a vector of parameters, and $\varepsilon_{i}$ is a normally distributed error term $N\left(0, \sigma^{2}\right)$; the probability of an individual's response to the bids $(B)$ offered will fall under one of four equations:

$$
\begin{gathered}
\operatorname{Pr}\left(B^{1}: \text { Yes, } B^{2}: \text { Yes }\right)=\operatorname{Pr}\left(x_{i} \alpha+\varepsilon_{i}>B^{1}, x_{i} \alpha+\varepsilon_{i}>B^{2}\right) \\
\operatorname{Pr}\left(B^{1}: \text { Yes, } B^{2}: N o\right)=\operatorname{Pr}\left(B^{1} \leq x_{i} \alpha+\varepsilon_{i}<B^{2}\right) \\
\operatorname{Pr}\left(B^{1}: \text { No, } B^{2}: \text { Yes }\right)=\operatorname{Pr}\left(B^{2} \leq x_{i} \alpha+\varepsilon_{i}<B^{1}\right) \\
\operatorname{Pr}\left(B^{1}: N o, B^{2}: N o\right)=\operatorname{Pr}\left(x_{i} \alpha+\varepsilon_{i}<B^{1}, x_{i} \alpha+\varepsilon_{i}<B^{2}\right)
\end{gathered}
$$

Using Equations (2) through (5), and following Lopez-Feldman [40], a log-likelihood function was constructed to estimate two parameters, $\alpha$ and $\sigma$, using maximum-likelihood estimation.

$$
\begin{aligned}
& \sum_{i=1}^{N}\left[c_{i}^{Y Y} \ln \left(\Phi\left(x_{i}^{\prime} i \frac{\alpha}{\sigma}-\frac{B^{2}}{\sigma}\right)\right)+c_{i}^{Y N} \ln \left(\Phi\left(x_{i}^{\prime} i \frac{\alpha}{\sigma}-\frac{B^{1}}{\sigma}\right)-\Phi\left(x_{i}^{\prime} i \frac{\alpha}{\sigma}-\frac{B^{2}}{\sigma}\right)\right)\right] \\
& +c_{i}^{N Y} \ln \left(\Phi\left(x i_{i} \frac{\alpha}{\sigma}-\frac{B^{2}}{\sigma}\right)-\Phi\left(x{ }_{i} \frac{\alpha}{\sigma}-\frac{B^{1}}{\sigma}\right)\right)+c_{i}^{N N} \ln \left(1-\Phi\left(x_{i} \frac{\alpha}{\sigma}-\frac{B^{2}}{\sigma}\right)\right)
\end{aligned}
$$


where $c_{i}^{Y Y}, c_{i}^{Y N}, c_{i}^{N Y}, c_{i}^{N N}$ are dummy variables that take the value of 0 or 1 depending on the choices made by individuals in response to the bids, and $\Phi$ is the standard normal cumulative distribution function.

\subsection{Survey Structure}

The NOAA panel also provided caveats to ensure the reliability of responses. Considering the scenarios are hypothetical, if not taken seriously, the values obtained might overestimate an individual's willingness to pay. Therefore, interviewers are encouraged to provide a rich context to guarantee that respondents will have enough information to make an informed decision [37]. As a result, the survey was structured after Bateman et al. [41] and Whitehead [42]. Prior to providing information on the scenarios, respondents were explained about the purpose of the study to guarantee that they would willingly collaborate with enumerators. Following this section, they were asked questions on their use and attitudes towards extension services on cereals crops to determine how acquainted they were with them and to identify users and non-users.

The valuation scenarios were also carefully designed to ensure farmers' stated values matched their formulated values but conservative enough to avoid an overestimation of the service that would lead to biased results [41]. Based on an assessment of the most pressing topics where there is a need for information, the study explored smallholder's willingness to pay for four different types of extension services: (1) integrated pest management, (2) postharvest handling, (3) business skills, and (4) land preparation, soil fertility, and water management; herein referred to as land management. Accordingly, farmers were presented with scenarios for each of these where they were given information about the content of a one-time comprehensive training, the location in which it would be delivered, and the payment mode. Furthermore, and before responding to the valuation question, they were also reminded about the household's budget constraints.

Researchers also warn about the possibility of protest responses to the valuation scenarios. Close-ended questionnaires do not provide incentives for unrealistic responses, but in some cases, respondents might react against the information presented or believe that they will not have to pay for such a scenario, which leads to unbiased estimates $[43,44]$. Consequently, after the valuation responses, the survey included a section with follow-up questions. Those responses that were regarded as non-valid or protest responses (5\%) were removed from the econometric analysis.

Finally, a section with questions about participant's demographic and socioeconomic characteristics was included to break down willingness to pay by categories. Arrow et al. [37] suggest including these variables to help interpret and to provide credibility to the responses.

\section{Results and Discussion}

Table 2 presents the results of the willingness to pay analysis for each of the four extension services as well as the coefficient of the covariates in the model. Farmers' WTP for extensions services ranged from 20,000 to 24,000 TZS (8-10 USD). Even though the differences are not large, the highest valued extension service was integrated pest management (IPM) followed by land management. The least valued advisory service was postharvest handling. The high value placed on IPM can be understood when considering the level of technical knowledge needed to apply pesticides. Moreover, pests pose a tangible threat to farmers' food security, thus making IPM-related information more valuable. On this note, it is worth mentioning that in the agricultural campaign prior to this study, farmers were hit by an outbreak of Fall Armyworm (FAW). A recent study conducted by Day et al. [45] estimate maize yield losses, attributable to FAW in Tanzania, to be up to $56 \%$. 
Table 2. Regression analysis results for farmer's willingness to pay for different type of extension services.

\begin{tabular}{|c|c|c|c|c|c|c|c|c|}
\hline \multirow[t]{2}{*}{ Variables } & \multicolumn{2}{|c|}{$\begin{array}{c}\text { Integrated Pest } \\
\text { Management }\end{array}$} & \multicolumn{2}{|c|}{ Postharvest Handling } & \multicolumn{2}{|c|}{ Business Skills } & \multicolumn{2}{|c|}{ Land Management } \\
\hline & $\begin{array}{l}\text { (1) } \\
\text { Alpha }\end{array}$ & $\begin{array}{c}(2) \\
\text { Sigma }\end{array}$ & $\begin{array}{c}\text { (3) } \\
\text { Alpha }\end{array}$ & $\begin{array}{c}(4) \\
\text { Sigma }\end{array}$ & $\begin{array}{c}\text { (5) } \\
\text { Alpha }\end{array}$ & $\begin{array}{c}(6) \\
\text { Sigma }\end{array}$ & $\begin{array}{c}(7) \\
\text { Alpha }\end{array}$ & $\begin{array}{c}(8) \\
\text { Sigma }\end{array}$ \\
\hline Male & $\begin{array}{c}2.923 \\
(1.901)\end{array}$ & & $\begin{array}{l}3.674 * \\
(1.896)\end{array}$ & & $\begin{array}{l}2.788^{*} \\
(1.677)\end{array}$ & & $\begin{array}{l}4.176^{* *} \\
(1.976)\end{array}$ & \\
\hline Age & $\begin{array}{c}-2.448^{* *} \\
(1.028)\end{array}$ & & $\begin{array}{l}-1.679 * \\
(1.007)\end{array}$ & & $\begin{array}{l}-0.586 \\
(0.902)\end{array}$ & & $\begin{array}{l}-1.348 \\
(1.087)\end{array}$ & \\
\hline $\begin{array}{c}\text { Literacy } \\
\text { level }\end{array}$ & 5.974 & & 4.997 & & 5.571 & & 6.374 & \\
\hline & (4.193) & & (4.109) & & (3.692) & & $(4.261)$ & \\
\hline $\begin{array}{l}\text { Education } \\
\text { level }\end{array}$ & 0.487 & & 1.002 & & 1.289 & & -0.270 & \\
\hline & $(0.869)$ & & $(0.865)$ & & $(0.786)$ & & $(0.922)$ & \\
\hline $\begin{array}{l}\text { Household } \\
\text { size }\end{array}$ & $-\underset{* * *}{1.230}$ & & 0.398 & & 0.322 & & -0.220 & \\
\hline & $(0.438)$ & & $(0.432)$ & & $(0.386)$ & & $(0.454)$ & \\
\hline Polygamist & $\begin{array}{l}-1.503 \\
(2.920)\end{array}$ & & $\begin{array}{l}-3.602 \\
(2.950)\end{array}$ & & $\begin{array}{l}-3.798 \\
(2.641)\end{array}$ & & $\begin{array}{l}-2.616 \\
(3.145)\end{array}$ & \\
\hline $\begin{array}{l}\text { Farming } \\
\text { experience }\end{array}$ & 0.160 & & 0.0614 & & -0.0358 & & 0.0439 & \\
\hline & $(0.098)$ & & $(0.096)$ & & $(0.087)$ & & $(0.104)$ & \\
\hline $\begin{array}{c}\text { Land } \\
\text { ownership }\end{array}$ & $1.485^{* *}$ & & 1.093 * & & $1.088^{*}$ & & $2.220^{* * *}$ & \\
\hline & $(0.625)$ & & $(0.622)$ & & $(0.618)$ & & $(0.713)$ & \\
\hline $\begin{array}{l}\text { Frequency of } \\
\text { visit }\end{array}$ & -1.042 & & -0.352 & & 0.594 & & 0.221 & \\
\hline & $(0.814)$ & & $(0.819)$ & & $(0.712)$ & & $(0.851)$ & \\
\hline $\begin{array}{c}\text { NAFAKA II } \\
\text { PO }^{\mathrm{a}}\end{array}$ & $4.101^{* *}$ & & 1.150 & & $3.869^{* *}$ & & $3.885 *$ & \\
\hline & (1.998) & & $(2.027)$ & & $(1.748)$ & & $(2.081)$ & \\
\hline $\begin{array}{l}\text { Access to } \\
\text { technology }\end{array}$ & 7.802 ** & & 4.675 & & $6.893^{* *}$ & & 5.519 & \\
\hline & (3.272) & & (3.281) & & $(2.934)$ & & (3.512) & \\
\hline $\begin{array}{l}\text { Agricultural } \\
\text { revenues b }\end{array}$ & 0.00115 & & $0.00160^{* *}$ & & $0.00151^{* *}$ & & $0.00145 *$ & \\
\hline & $(0.000745)$ & & $(0.000702)$ & & $(0.000649)$ & & $(0.000761)$ & \\
\hline $\begin{array}{l}\text { Off-farm } \\
\text { income }\end{array}$ & $0.00179^{*}$ & & 0.000285 & & 0.000247 & & 0.000320 & \\
\hline & $(0.000988)$ & & $(0.000868)$ & & $(0.000784)$ & & $(0.00102)$ & \\
\hline Kilombero & $\begin{array}{l}2.042 \\
(2.887)\end{array}$ & & $\begin{array}{l}6.507^{* *} \\
(2.907)\end{array}$ & & $\begin{array}{c}0.399 \\
(2.525)\end{array}$ & & $\begin{array}{l}5.564^{*} \\
(2.968)\end{array}$ & \\
\hline Mbozi & $\begin{array}{l}5.222 * * \\
(2.506)\end{array}$ & & $\begin{array}{c}7.633^{* * *} \\
(2.596)\end{array}$ & & $\begin{array}{c}3.164 \\
(2.244)\end{array}$ & & $\begin{array}{c}10.74^{* * *} \\
(2.662)\end{array}$ & \\
\hline Mbarali & $\begin{array}{c}4.509 \\
(3.054)\end{array}$ & & $\begin{array}{l}5.129^{*} \\
(3.031)\end{array}$ & & $\begin{array}{l}1.368 \\
(2.709)\end{array}$ & & $\begin{array}{c}4.876 \\
(3.120)\end{array}$ & \\
\hline Constant & $\begin{array}{l}11.73^{*} \\
(6.320)\end{array}$ & $\begin{array}{c}16.50 * * * \\
(0.849)\end{array}$ & $\begin{array}{l}-1.255 \\
(6.474)\end{array}$ & $\begin{array}{c}16.35^{* * *} \\
(0.907)\end{array}$ & $\begin{array}{l}-3.558 \\
(5.715)\end{array}$ & $\begin{array}{c}14.45^{* * *} \\
(0.762)\end{array}$ & $\begin{array}{l}0.360 \\
(6.576)\end{array}$ & $\begin{array}{c}16.78^{* * *} \\
(0.998)\end{array}$ \\
\hline $\begin{array}{l}\text { Willingness } \\
\text { to pay } \mathrm{b}\end{array}$ & 23.68 & & 19.71 & & 20.88 & & 21.58 & \\
\hline Observations & 475 & 475 & 482 & 482 & 481 & 481 & 478 & 478 \\
\hline
\end{tabular}

Standard errors in parentheses, ${ }^{* * *} p<0.01,{ }^{* *} p<0.05,{ }^{*} p<0.1$. ${ }^{a}$ Producer Organization working with NAFAKA II.

$\mathrm{b}$ Thousands of Tanzanian shillings.

Male farmers significantly valued postharvest handling, business skills, and land management AES more than their female counterparts. The lower WTP exhibited by women could be linked to how financial decisions are made at the household level and/or a difference in assets with male farmers [46]. Additionally, farmer's age had a significant and inverse relationship with the WTP; the younger the farmer, the higher the WTP specifically for IPM and postharvest handling extension services. The capacity of youth to innovate and their flexibility to try new technologies increases 
the demand for knowledge [47]. Therefore, they place a higher value on extension services. Household size is a factor that affects a family's budget constraints and, therefore, has an inverse relationship with WTP specifically for IPM. This might be related to the high value of this AES compared to the rest, meaning that any shock can affect the household's ability to pay for it.

NAFAKA II works to strengthen Producer Organizations' human and institutional capacities. Continuous efforts to support these networks of farmers seem to increase its members' WTP for extension services, which might be related to a higher awareness of the impact of trainings. Access to agricultural technologies also increased farmers' WTP for IPM and business skills. The large number of available technologies to combat pests drive the farmers' need to gain knowledge on their effective use; thus increasing the need for extension services. This, in turn, also enhances farmer's adoption of technologies [48]. In addition, higher yields as a result of the use of crop protectants could lead to higher revenues, which requires knowledge on financial management and marketing.

Land ownership significantly increased farmer's WTP for all the four services, as also found by Ulimwengu and Sanyal [49] in Uganda. Having secure property rights promotes sustainable land use, increases farmers' access to financial services and incentivize investment [50]. Agricultural revenues increased WTP for postharvest handling, business skills, and land management. Higher revenues impact farmers' ability to reinvest in trainings to increase productivity. However, agricultural revenues seemed to have a minimal influence on farmer's WTP for IPM. Historical field evidence from the NAFAKA II and Africa RISING projects, collected through focus group discussions (FGDs), suggests that this might be because smallholders know that, independently of the revenues generated, they need to invest in IPM trainings to avoid losses. On the contrary, off-farm income had a significant and positive influence on farmers' WTP for IPM. This could be a risk-free revenue stream that might be used to acquire knowledge on how to mitigate shocks that have impacted crop yields in the past, like FAW. de Janvry and Sadoulet [51] highlight the contributions of the non-farm economy to reduce rural poverty. Off-farm income, as a means of diversification, can increase farmer's competitiveness and resilience. In addition, the results obtained for agricultural revenues and non-agricultural income in this study are consistent with those of Ajayi [52] and Ulimwengu and Sanyal [49] who found a positive influence of these variables on farmers' WTP for extension services.

Finally, the location the respondent belongs to also influences the WTP for AES. In this study, Kilolo district is the omitted variable. Farmers in Mbozi had a significantly higher willingness to pay for IPM, which could be attributed to previous maize production losses related to FAW in the district. There was a positive and significant relationship with postharvest handling trainings in the three districts. Postharvest losses can reach levels off $40 \%$ in Tanzania [53], and therefore, farmers understand the importance of acquiring knowledge on the subject. Farmers WTP for land management trainings was found to have a positive relationship for farmers located in Kilombero and Mbozi districts. In Kilombero, this might be because rice is produced under rain-fed conditions, which increases the need for information on how to appropriately prepare the land to achieve higher yields. In Mbozi, given that this is a high-yielding maize area, smallholders require training and information on soil fertility and conservation techniques to maintain high levels of productivity.

\section{Conclusions and Policy Implications}

Government and donor-funded projects have historically subsidized extension services in developing countries. In agricultural-based economies, government extension officers face challenges to deliver these services to farmers given the variety of crops, geographic coverage, and limited funding available. Consequently, donor programs are often implemented to overcome these conundrums. However, this arrangement creates additional challenges, since donor-funded projects have a limited lifespan and, hence, make extension programs vulnerable to shocks and compromises the sustainability of knowledge transfer over time. As a result, guaranteeing sustainable and demand-driven provision of extension services has long been a topic of discussion in the development community. The USAID Feed the Future NAFAKA II and the Africa RISING projects created a system of community-based 
extension services by recruiting and training Village-Based Agricultural Advisors (VBAAs) and Producer Organizations (POs) leaders to increase access to improved agricultural inputs, while providing agricultural extension services. The programs hypothesized that, as they phase out, there will be a market for VBAAs and POs to provide extension services in exchange for a fee, whereby these qualified providers are readily available at the village level to assist farmers to fill knowledge gaps.

Using a double-bounded dichotomous choice experiment, we estimated farmer's willingness to pay for four types of extension services: IPM, postharvest handling, business skills, and land management. The WTP figures ranged from 20,000 to 24,000 TZS (8-10 USD) depending on the type of AES. Variables such as sex, age, household size, land ownership, participation in a NAFAKA II PO, agricultural revenues, off-farm income, location, and access to technology influenced smallholders' willingness to pay for AES.

Stakeholders from the public and private sector should prioritize policies and the coordination of actions that promote participation of women and youth in rural areas. As youth tend to move away from agriculture, there is a need for investments to provide opportunities that enable them to work in the sector and thrive in their communities. Furthermore, women's empowerment activities should focus on fostering a more inclusive joint decision-making activity within households. Secure land rights can influence a community's ability to achieve self-reliance. Therefore, interinstitutional coordination with local government authorities and projects that address land ownership challenges should be strengthened. Partnerships with the private sector can greatly assist in strengthening the input supply chain to guarantee access to improved inputs and equipment that, coupled with institutional and human capacity building of farmers' organizations, can have a positive impact on productivity and agricultural revenues. Policymakers should also further explore the potential of the non-farm economy to generate diversified incomes as additional revenue streams to mitigate risks from agriculture.

These results provide evidence that farmers place a monetary value on extension services and suggest the existence of an implicit market for them. In an effort to increase the availability and efficiency of extension services, one of the overarching policy debates in the development arena has been to analyze the role of cooperatives and farmer organizations in enhancing smallholders' access to agricultural services. This study sheds light on the feasibility of a farmer-led model as a community-driven alternative to increase the plurality of extension services providers at the village level and. thus, delink extension services from public and donor funding as a path to achieve sustainable rural development.

Author Contributions: Conceptualization, J.F. and H.S.; methodology, R.A.; software, R.A.; validation, R.A., H.S., J.F., S.M., and H.M.; formal analysis, R.A.; investigation, R.A. and H.S.; resources, R.A., H.S., J.F., S.M., and H.M.; data curation, R.A. and S.M.; writing —original draft preparation, R.A. and H.S.; writing —review and editing, J.F. and H.S.; visualization, R.A., H.S., J.F., S.M., and H.M.; supervision, J.F. and H.S.; project administration, J.F. All authors have read and agreed to the published version of the manuscript.

Funding: This work was supported by the United States Agency for International Development (USAID) under grant numbers AID-621-LA-16-00001 and BFS-G-11-00002 for NAFAKA II and Africa RISING, respectively.

Conflicts of Interest: The authors declare no conflict of interest. The funders had no role in the design of the study; in the collection, analyses, or interpretation of data; in the writing of the manuscript, or in the decision to publish the results.

\section{References}

1. World Bank. Poverty and Shared Prosperity 2018: Piecing Together the Poverty Puzzle; The World Bank Group: Washington, DC, USA, 2018.

2. FAO; IFAD; UNICEF; WFP; WHO. The State of Food Security and Nutrition in the World 2019: Safeguarding against Economic Slowdowns and Downturns; CC BY-NC-SA 3.0 IGO; FAO: Rome, Italy, 2019.

3. OECD. Agriculture in Sub-Saharan Africa: Prospects and Challenges for the Next Decade; OECD Publishing: Paris, France, 2016. [CrossRef]

4. FAO. Transforming the World through Food and Agriculture: FAO and the 2030 Road for Sustainable Development; Food and Agriculture Organization of the United Nations: Rome, Italy, 2019. 
5. Benin, S. Impacts of CAADP on Africa's Agricultural-Led Development; International Food Policy Research Institute: Washington, DC, USA, 2016; Volume 1553.

6. Shimeles, A.; Verdier-Chouchane, A.; Boly, A. Building a Resilient and Sustainable Agriculture in Sub-Saharan Africa; Springer Nature: Basingstoke, UK, 2018.

7. World Bank. World Bank Indicators; Catalog, W.B., Ed.; The World Bank Group: Washington, DC, USA, 2020.

8. Shee, A.; Azzarri, C.; Haile, B. Farmers' willingness to pay for improved agricultural technologies: Evidence from a field experiment in Tanzania. Sustainability 2020, 12, 216. [CrossRef]

9. FAOSTAT. FAOSTAT Database; FAO: Rome, Italy, 2020.

10. The United Republic of Tanzania. National Agricultural Policy; Ministry of Agriculture, Food Security and Cooperatives: Dar Es Salaam, Tanzania, 2013.

11. Rutatora, D.F.; Mattee, A.Z. Major agricultural extension providers in Tanzania. Afr. Study Monogr. 2001, 22, 155-173. [CrossRef]

12. Lameck, W. Decentralization and the Quality of Public Service Delivery in Tanzania: A Study of the Delivery of Agricultural Extension Services in Morogoro Municipality and Hai District Council. Ph.D. Thesis, Vrije Universiteit Amsterdam, Amsterdam, The Netherlands, 2017.

13. The United Republic of Tanzania. Local Government Reform Programme II (Decentralization by Devolution): Vision, Goals and Strategy July 2009-June 2014; Prime Minister's Office Regional Administration and Local Government: Dodoma, Tanzania, 2009.

14. Kyaruzi, A.; Mlozi, M.; Busindi, I. Gender based effectiveness of agricultural extension agents' contacts with smallholder farmers in extension services delivery: A case of Kilosa District, Tanzania. J. Contin. Educ. Ext. 2010, 2, 85-93.

15. The United Republic of Tanzania. Agricultural Sector Development Programme 2 (ASDP II); Prime Minister's Office Regional Administration and Local Government: Dodoma, Tanzania, 2016.

16. World Bank. Enhancing Agricultural Innovation: How to Go Beyond the Strengthening of Research Systems; World Bank Group: Washington, DC, USA, 2006.

17. Sseguya, H.; Mazur, R.; Abbott, E.; Matsiko, F. Information and communication for rural innovation and development: Context, quality and priorities in southeast Uganda. J. Agric. Educ. Ext. 2012, 18, 55-70. [CrossRef]

18. Wilson, R.T.; Lewis, J. The Maize Value Chain in Tanzania: A Report from the Southern Highlands Food Systems Programme; Food and Agriculture Organization of the United Nations: Rome, Italy, 2015.

19. Mtaki, B. Grain and Feed Annnual: Tanzanian Corn, Wheat and Rice Report; USDA Foreign Agricultural Service: Dar es Salaam, Tanzania, 2017.

20. MAFAP. Review of Food and Agricultural Policies in the United Republic of Tanzania 2005-2011: Country Report; Food and Agriculture Organization of the United Nations: Rome, Italy, 2013.

21. USAID. Famine Early Warning Systems Network: Tanzania Market Fundamentals Summary; USAID's Bureau for Humanitarian Assistance: Dar Es Salaam, Tanzania, 2018.

22. Ley, G. Tanzania Country Profile; Africa Soil Health Consortium: Nairobi, Kenya, 2015.

23. Hella, J. Study to Establish Return to Investment in Agricultural Extension Service in Tanzania; Ministry of Agriculture, Food Security and Cooperatives: Dar Es Salaam, Tanzania, 2013.

24. USAID. A Decade of Progress: Feed the Future Snapshot; United States Agency for International Development: Washington, DC, USA, 2018.

25. ACDI/VOCA. Feed the Future Tanzania NAFAKA FY16 Annual Report: October 2016 to September 2017; ACDI/VOCA: Washington, DC, USA, 2017.

26. Africa Research in Sustainable Intensification for the Next Generation: Sustainable Intensification of Key Farming Systems in East and Southern Africa. 2014. Available online: https://cgspace.cgiar.org/handle/10568/ 108832 (accessed on 20 August 2020).

27. Davis, K.; Nkonya, E.; Kato, E.; Mekonnen, D.A.; Odendo, M.; Miiro, R.; Nkuba, J. Impact of farmer field schools on agricultural productivity and poverty in East Africa. World Dev. 2012, 40, 402-413. [CrossRef]

28. Wellard, K.; Rafanomezana, J.; Nyirenda, M.; Okotel, M.; Subbey, V. A review of community extension approaches to innovation for improved livelihoods in Ghana, Uganda and Malawi. J. Agric. Educ. Ext. 2013, 19, 21-35. [CrossRef] 
29. Kiptot, E.; Franzel, S. Developing sustainable farmer-to-farmer extension: Experiences from the volunteer farmer-trainer approach in Kenya. Int. J. Agric. Sustain. 2019, 17, 401-412. [CrossRef]

30. Simpson, B.M.; Franzel, S.; Degrande, A.; Kundhlande, G.; Tsafack, S. Farmer-to-Farmer Extension: Issues in Planning and Implementation; USAID: Washington, DC, USA, 2015.

31. Shekara, P. Status of Private Extension in India; National Institute of Agricultural Extension Management (MANAGE): Hyderabad, India, 2004.

32. Kiptot, E.; Franzel, S. Voluntarism as an investment in human, social and financial capital: Evidence from a farmer-to-farmer extension program in Kenya. Agric. Hum. Values 2014, 31, 231-243. [CrossRef]

33. USAID. Country Development Cooperation Strategy: Tanzania's Socioeconomic Transformation toward Middle Income Status by 2025 Advanced; USAID: Washington, DC, USA, 2014.

34. Carson, R.T.; Mitchell, R.C. Contingent valuation and the legal arena. In Valuing Natural Assets: The Economics of Natural Resource Damage Assessment; RFF Press: New York, NY, USA, 1993; pp. 231-244.

35. Portney, P.R. The contingent valuation debate: Why economists should care. J. Econ. Perspect. 1994, 8, 3-17. [CrossRef]

36. Carson, R.T.; Mitchell, R.C.; Hanemann, W.M.; Kopp, R.J.; Presser, S.; Ruud, P.A. A Contingent Valuation Study of Lost Passive Use Values Resulting from the Exxon Valdez oil Spill: A Report to the Attorney General of Alaska; University Library of Munich: Munich, Germany, 1992.

37. Arrow, K.; Solow, R.; Portney, P.R.; Leamer, E.E.; Radner, R.; Schuman, H. Report of the NOAA Panel on Contingent Valuation; NOAA: Washington, DC, USA, 1993; pp. 4601-4614.

38. Bishop, R.C.; Heberlein, T.A. Measuring values of extramarket goods: Are indirect measures biased? Am. J. Agric. Econ. 1979, 61, 926-930. [CrossRef]

39. Hanemann, M.; Loomis, J.; Kanninen, B. Statistical efficiency of double-bounded dichotomous choice contingent valuation. Am. J. Agric. Econ. 1991, 73, 1255-1263. [CrossRef]

40. Lopez-Feldman, A. Introduction to Contingent Valuation Using Stata; University Library of Munich: Munich, Germany, 2012.

41. Bateman, I.J.; Carson, R.T.; Day, B.; Hanemann, M.; Hanley, N.; Hett, T.; Jones-Lee, M.; Loomes, G.; Mourato, S.; Pearce, D.W. Economic Valuation with Stated Preference Techniques: A Manual; Edward Elgar Publishing Ltd.: Cheltenham, UK, 2002.

42. Whitehead, J.C. A practitioner's primer on the contingent valuation method. In Handbook on Contingent Valuation; Edward Elgar Publishing: Cheltenham, UK, 2006; pp. 66-91.

43. Jorgensen, B.S.; Syme, G.J.; Bishop, B.J.; Nancarrow, B.E. Protest responses in contingent valuation. Environ. Resour. Econ. 1999, 14, 131-150. [CrossRef]

44. Strazzera, E.; Scarpa, R.; Calia, P.; Garrod, G.; Willis, K.G. Modelling Zero Bids in Contingent Valuation Surveys; CRENoS: Cagliari, Italy, 2000.

45. Day, R.; Abrahams, P.; Bateman, M.; Beale, T.; Clottey, V.; Cock, M.; Colmenarez, Y.; Corniani, N.; Early, R.; Godwin, J. Fall armyworm: Impacts and implications for Africa. Outlooks Pest Manag. 2017, 28, 196-201. [CrossRef]

46. Fisher, B.; Naidoo, R. The geography of gender inequality. PLoS ONE 2016, 11, e0145778. [CrossRef] [PubMed]

47. Onemolease, E.; Alakpa, S. Determinants of adoption decisions of rural youths in the Niger delta region of Nigeria. J. Soc. Sci. 2009, 20, 61-66. [CrossRef]

48. Larochelle, C.; Alwang, J.; Travis, E.; Barrera, V.H.; Dominguez Andrade, J.M. Did you really get the message? Using text reminders to stimulate adoption of agricultural technologies. J. Dev. Stud. 2019, 55, 548-564. [CrossRef]

49. Ulimwengu, J.; Sanyal, P. Joint estimation of farmers' stated willingness to pay for agricultural services. In International Food Policy Research Institute Discussion Paper; IFPRI: Washington, DC, USA, 2011; Volume 1070.

50. Deininger, K.W. Land Policies for Growth and Poverty Reduction; World Bank Publications and Oxford University Press: Washington, DC, USA, 2003.

51. De Janvry, A.; Sadoulet, E. Achieving the Sustainable Development Goal on Poverty Eradication; Fondation pour les études et recherches sur le développement international (FERDI): Clermont-Ferrand, France, 2017. 
52. Ajayi, A. An assessment of farmers' willingness to pay for extension services using the contingent valuation method (CVM): The case of Oyo State, Nigeria. J. Agric. Educ. Ext. 2006, 12, 97-108. [CrossRef]

53. Mutungi, C.; Muthoni, F.; Bekunda, M.; Gaspar, A.; Kabula, E.; Abass, A. Physical quality of maize grain harvested and stored by smallholder farmers in the Northern highlands of Tanzania: Effects of harvesting and pre-storage handling practices in two marginally contrasting agro-locations. J. Stored Prod. Res. 2019, 84, 101517. [CrossRef]

Publisher's Note: MDPI stays neutral with regard to jurisdictional claims in published maps and institutional affiliations.

(C) 2020 by the authors. Licensee MDPI, Basel, Switzerland. This article is an open access article distributed under the terms and conditions of the Creative Commons Attribution (CC BY) license (http://creativecommons.org/licenses/by/4.0/). 